
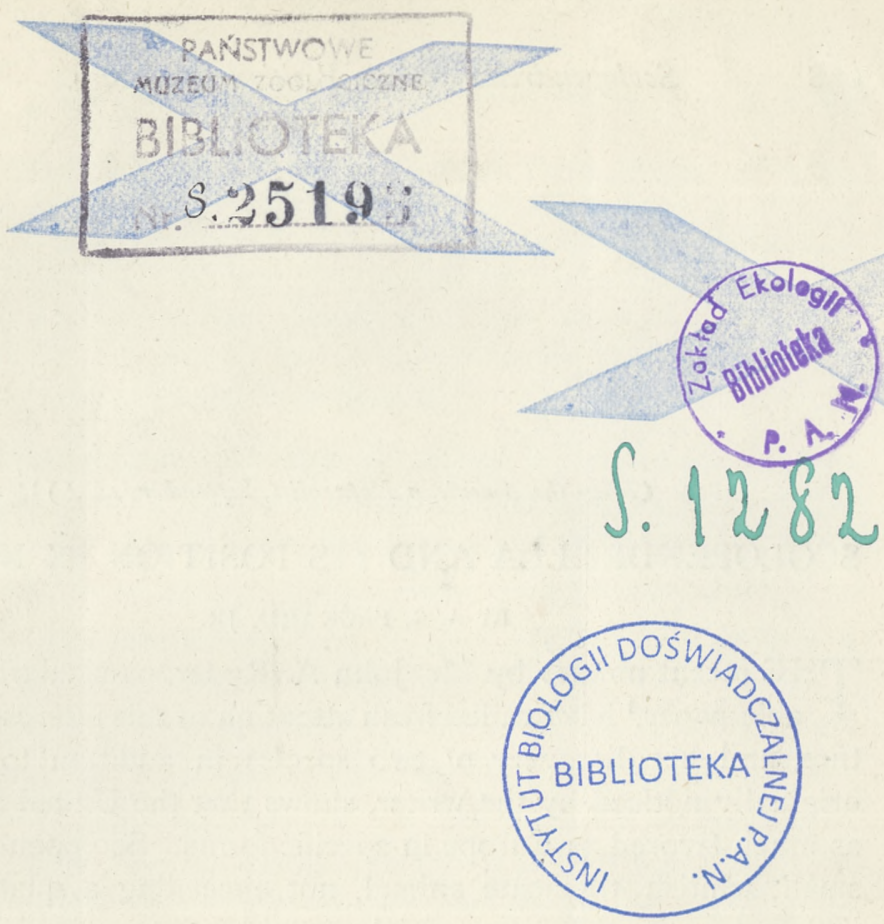

tould olo \&, 1353 rcin.org.pl 
(From the American Naturalist, September, 1881.)

\title{
SCOLOPENDRELLA AND ITS POSITION IN NATURE.
}

\author{
BY A. S. PACKARD, JR.
}

THE, recent notices by $\mathrm{Mr}$. John A. Ryder, particularly his last 1 able paper, ${ }^{1}$ have called fresh attention to this interesting creature, and his discovery of two species in addition to the one originally noticed by the writer, shows that the United States are as much favored as Europe in specific forms. Scolopendrella is a small; whitish tracheate animal, not exceeding a quarter of an inch in length, with a superficial resemblance to a myriopod, such as Scolopendra, having a pair of well developed, five-jointed legs to each abdominal as well as thoracic segment; its name ending in a diminutive gives evidence of the original opinion of its discoverer, that it was a small myriopod, like Scolopendra, the centipede. In deference to the general opinion of naturalists in our "Guide to the Study of Insects," and our "Zoology" we have let it remain among the Myriopods, but it occupied an uncertain place, as we waited for more light upon the subject of its affinities, and for time to study it with more care.

Attention was first called to the existence of this type of Tracheates in the New World by a brief notice which appeared in the Proceedings of the Boston Society of Natural History, Vol. $\mathrm{XVI}$, p. III, I873, which read as follows:

"For nearly two years we have had in the Museum of the Peabody Academy of Science a specimen of Scolopendrella, detected September 8, by Mr. C. A. Walker, under a board in the grounds of the museum. It is nearly related to Scolopendrella immaculata Newport, and if new may be called S. americana. Of the remarkable features in the structure of this animal I do not now propose to speak. It has, however, in the head and antennæ a strong re-

${ }^{1}$ The structure, affinities and species of Scolopendrella, Proc. Acad. Nat. Sc. Phil,, I 88 I, p. 79. 
semblance to Campodea, and in this and in the presence of spines at the base of the legs, and in other characters, it bears a striking similarity to the Campodeæ and the Thysanura, as already indicated by Lubbock. It may be regarded as a connecting link between the Thysanura and Myriapoda, and shows the intimate relation of the Myriapods and the Hexapods, perhaps not sufficiently appreciated by many zoölogists."

It will thus be seen that eight years ago we called attention to the strongly marked Thysanurous features of Scolopendrella, a fact apparently overlooked by Mr. Ryder, who quotes at length, however, the opinion of Menge in I85 I, who, therefore, was the first to call attention at some length in an able paper, to the structure of Scolopendrella, of which Mr. Ryder gives a useful abstract.

Up to last year Scolopendrella had been left undisturbed in its niche among the Myriopoda, when in I880, in this journal, ${ }^{1} \mathrm{Mr}$. Ryder boldly suggested that it should be regarded as the type of a distinct order of articulates, and called attention anew to its close relationship to the Thysanura; and in his last paper gives the characters of the order, and a list of the known species, with descriptions of a new one, under the name Scolopendrella gratice. He also figures a form very closely allied to, if not identical with S. notacantha of Europe.

Having collected considerable material, notes and drawings for a monographic account of our Thysanura, and having worked out the external structure of Campodea and Lepisma, we have long been anxious to study with care the structure of Scolopendrella. A species occurred at Salem, Massachusetts, which we called provisionally S. americana, deferring a description of it until we could get from Europe specimens of Newport's S. immaculata. Writing for several years past without success to naturalists in England, Belgium and Denmark, during the past spring we had the good fortune to receive several specimens of this species from Bohemia, through the kindness of Dr. Latzel, author of a work on AustrioBohemian myriopods, which we have not, however, seen.

I afterwards, in 1874 , found two specimens of my Salem form under stones at the mouth of a small cave (White's cave, Jr.) near Mammoth cave, and the same spring Mr. Sanborn collected one in a cave near Dismal creek, near Mammoth cave.

\footnotetext{
${ }^{1}$ Scolopendrella as the type of a new order of Articulates (Symphyla), AmericaN NATURALIST, May, I88o.
} 
On comparing them with seven well preserved specimens from Bohemia, I find no differ-

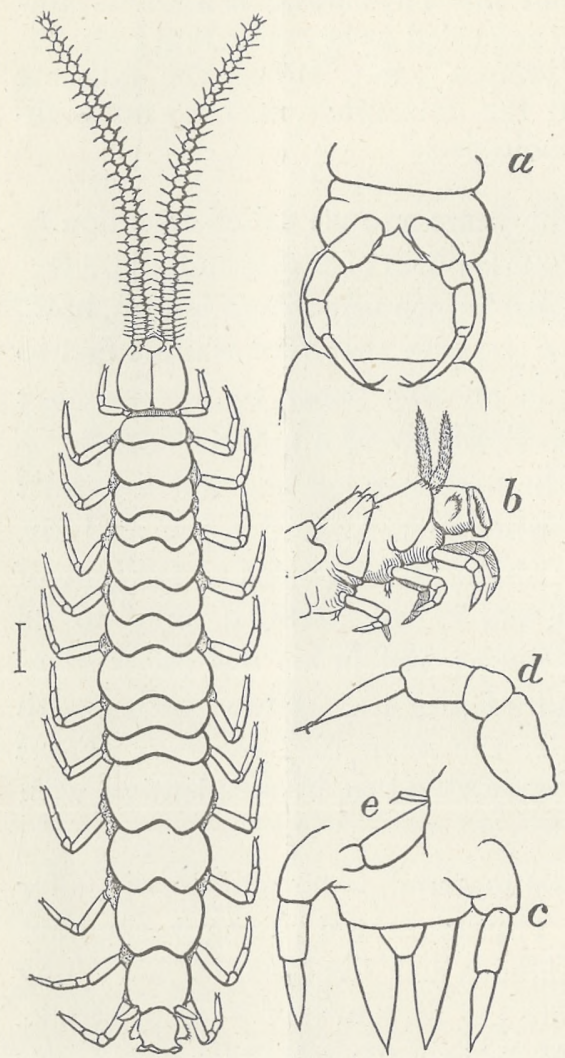

FIG. I.-Scolopendrella immaculata highly magnified; $a$, second thoracic segment with legs; $b$, end of body, showing the caudal stylets; $d$, a leg, first joint not shown; $c$, end of the body, showing caudal stylets; $e$, base of leg with supplementary appendage. Emerton and Packard, del. ence, except that our form has rather longer and slenderer antennæ than any of the Bohemian specimens; the American cave individuals have uniformly thirty-three joints, and the spaces between the nodes are longer than in the Bohemian ones, which have from twentyone to thirty-two joints. We do not, however, regard this as a specific character in so variable a genus as this, and it may be that out-of-door forms may occur in this country with shorter and stouter antennæ, like the European one. We regard, then, our S. americana (no description published) as a synonym of S. immaculata Newport.

The adjoining figure, drawn by Mr. Emerton from the specimens from White's cave, Jr., with the details of the caudal appendages drawn with the camera from the Salem specimen, will represent this form, which is $5 \mathrm{~mm}$. in length.

Let us now look at theThysanurous features of the Scolopendrella, and then compare it with the Myriopods, such as our common Lithobius.

The structure of the head is exactly as in Campodea, the form of the epicranium being the same, having a well marked median suture, while the posterior edge of the clypeus is angular, the apex of the triangular edge meeting the epicranial suture, as 
in Campodea; the labrum is small and rounded in front (what Menge calls the labrum is in reality the clypeus). The mode of insertion of the antennæ and their shape is as in Campodea. The form of the clypeus and of the antennæ are entirely unlike those of any Myriopod known to us. The mouth-parts bear the same relation to the head, and are sunken or withdrawn into the head in the same peculiar manner, as according to Meinert and our own repeated observations, characterizes the Thysanura. The bases of the jaws and maxillæ are contained deep in the cavity of the head or epicranium, only the ends projecting out, as in Campodea. ${ }^{1}$ The mandibles are slightly curved, toothed, and constructed on the Campodea type; the maxillæe are long and slender, and in a side view are seen through the walls of the thin epicranium, appearing much as in Campodea. Their structure is in general like that of Campodea.

The legs are five-jointed and, as observed by Menge and Ryder, end in two claws, as in Campodea; in Myriopods there are six joints, and always a single large claw. The stigmata we have found to open between and just behind the legs, as Mr. Ryder has stated, but we have been unable to find any in the first and second segments behind the head; those corresponding to the prothoracic and mesothoracic segments of hexapodous insects.

The v-shaped opening, supposed to be either sexual or to correspond to the sucking organ of Thysanura, we have observed only in the fourth segment, or that corresponding to the first abdominal segment of Thysanura and insects in general. We are disposed to regard this as the homologue of the sucker of

${ }^{1}$ Meinert (Annals and Mag. Nat. Hist. I867, p. 362), ascribes great importance to the "position of the first two pairs of appendages of the mouth with reference to the skull." In most insects, and in the Myriopods, the jaws for example act transversely and articulate with the epicranium by means of a hinge-joint. In the Thysanura the bases of the mandibles and maxillæ are retracted within the cavity of the epicranium, and are buried in muscles, while generally only their points project outside of their mouth. This is the case with Thysanura, both in Campodea and allies (our suborder Cinura), and in the Poduræ, or Collembola, but in the highest Thysanura, Lepisma, the jaws are external and articulated to the skull outside of the mouth, and thus Lepisma approaches the true hexapod insects, and affords a passage from one type of head to the other. Scolopendrella, with its feeble jaws and maxillæ buried in the mouth and enveloped in muscles, is throughout Campodea-like, and essentially unlike the Myriopods, such as Lithobius and Scolopendra with their large, powerful, biting jaws, hinged to the thick, solid epicranium and acting transversely. 
Poduræ, and which we have designated as the collophore; the occurrence of this opening on the fourth ring indicates that in Scolopendrella we may distinguish between a series of three thoracic segments and about nine or ten abdominal segments.

Now examining the supposed myriopodous features of Scolopendrella, we find that they consist in the identity in form of all the body segments behind the head, and in the fact that each segment bears a pair of functional several-jointed legs. In Machilis, however, the thoracic segments grade almost imperceptibly into the abdominal arthromeres or somites; though in Lepisma, and especially in Japyx and Campodea the thoracic segments are clearly differentiated from the abdomen.

Now the possession of functional jointed abdominal legs by Scolopendrella does not imply that it is necessarily a Myriopod; we have seen that the feet differ in important respects from those of the centipede, and the presence or absence of abdominal feet is not an ordinal or very important character, for the head characters are both in Hexapods as well as in Arachnida and Myriopods, of the most importance in separating orders and subclasses. Turning now to the Thysanura, we see that Campodea has a series of one-jointed abdominal appendages which are, as we have observed, very movable while the insect is running. They appear to be rudimentary locomotive appendages. Those of Machilis are much better developed and are still more leg-like; the two pairs of terminal shorter stylets of Lepisma we have observed are used as prop-legs, so that the transition from the legs of Machilis to Scolopendrella is not a very abrupt one. We therefore conclude that the sum of the characters of Scolopendrella are Thysanurous, and that the homogeneity of the body segments and the five-jointed legs which has led to their being regarded as Myriopods, have misled naturalists; Scolopendrella seems to us to be only analogous to the Myriopods as regards its feet. The presence of the two caudal stylets is also a Thysanurous feature; these organs we should regard as homologous with the stylets of Lepisma and the forceps of Japyx. Menge and Ryder regard them as spinning organs, and we would agree with this opinion, as in one of the specimens from Bohemia, we could see the ducts leading into each stylet, from one of which a silken thread projected. From Menge's statement that the opening of the oviduct lies immediately above the anus, we should dissent on general grounds, as 
in no known arthropod is this the case. Although we have not been able to find the opening, it should be looked for between the second and third segments from the anus.

The view of Menge and of Ryder that "these singular animals should be separated from the myriopods proper," will, it seems to us, be concurred in by any one who may carefully examine into the matter.

Now arises the question as to the real position of the Scolopendrella. Mr. Ryder gives the following results of his able investigations:

"This form as interpreted above, becomes of the highest interest to the zoologist, and if the writer is not mistaken, the biunguiculate legs and their nearly complete correspondence in number with the rudimentary abdominal and functional thoracic limbs of the Thysanura, especially Machilis and Lepisma, which also have basal appendages to the legs, indicate as much affinity with insects as with myriopods, and may indeed be looked upon, perhaps, as representing the last survival of the form from which insects may be supposed to have descended. I name the new group Symphyla, in reference to the singular combination of myriopodous, insectean and Thysanurous characters which it presents." He regards the Symphyla as an order with one family, the Scolopendrellide of Newport. We had been ready to adopt this order, though we felt uncertain as to its position; but on a re-examination of the structure of $S$. immaculata, and from the information afforded by Menge and Ryder, have been led to question whether the Symphyla should be regarded as an independent order of Tracheata, and if so, whether they should be included with the Thysanura among the genuine insects or not. We see no reason why the Thysanura should not be regarded as an order standing at the bottom of the hexapodous series, and constituting an eighth order of Hexapoda. We regard the Collembola of Lubbock as a suborder of Thysanura; we have in the seventh edition of our "Guide to the study of Insects," I880, thrown the Lepismatidæ, Campodeæ and Japygidæ into a new suborder called Cinura. Now the question arises, have the Symphyla characters sufficiently distinctive to keep them apart as a separate order, next to and below the Thysanura as a whole, or should they be regarded as a third suborder of Thysanura equivalent to the Collembola on the one hand, and to the Cinura on the other? We are inclined to the latter view. 
The distinctive Thysanurous character of the Symphyla, are the form of the head as a whole, that of the epicranium, and of the clypeus and the small labrum, as well as the mode of insertion of the antennæ, and their form. The mouth parts, $i . e_{\text {. }}$, the mandibles, maxillæ and labium, have the essential form of Campodea; the caudal stylets are insectean. These characters do not remove them more than by one family from the Campoder and Japygidæ. They also have what is possibly a collophore; the spiracles are much as in Japyx, but situated between the legs, though the presence or absence of spiracles is so variable in the Thysanura as to be unimportant. The differential characters are the presence of five-jointed functional legs, and the dorsal scutes of the somites, the latter homonomous; but even here the claws are exactly as in Campodea, and we see an approach to the multiarticulate legs in Machilis, and the two pairs of long proplegs in Lepisma. Under these circumstances we should include the Symphyla as a suborder of Thysanura. At the same time we wish to bear testimony to the ability and good judgment shown by Mr. Ryder in dealing with a most difficult problem, and offer our own views for the consideration of zoollogists. None the less as pointed out by Mr. Ryder, is the view (we have also long held) well founded, that Scolopendrella is an ancestral, synthetic form. In this respect it stands side by side with the Campodea. The structure of this synthetic type also shows how close is the relationship between the hexapndous insects and the Myriopods, which are more closely related in most respects than the Hexapoda and Arachnida. We are also confirmed in the view that the Hexapods, Arachnids and Myriopods are too closely related to be regarded as independent classes, and should be regarded as subdivisions (subclasses) of Tracheata.
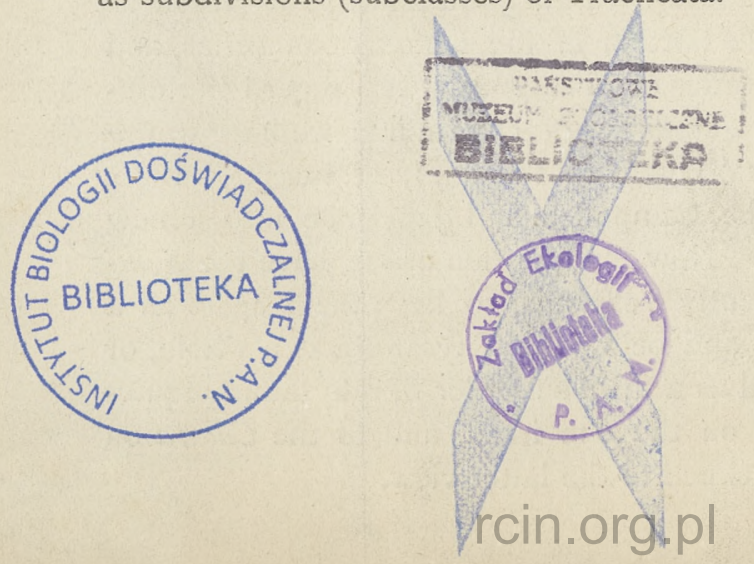